\title{
Antitumor Activity of Dendrophthoe falcata against Ehrlich Ascites Carci- noma in Swiss Albino Mice
}

\author{
Nipun Dashora, Vijay Sodde, Jaykumar Bhagat, Kirti S. Prabhu and Richard Lobo*
}

Department of Pharmacognosy, Manipal College of Pharmaceutical Sciences, Manipal University, Manipal-576 104, Karnataka, India

\begin{abstract}
The objective of the present study is to explore the anticancer activity of the ethanolic and aqueous extracts of the Dendrophthoe falcata in Swiss albino mice against Ehrlich Ascites Carcinoma (EAC) cell line. Anticancer activity of ethanolic and aqueous extracts of D. falcata was evaluated in EAC Swiss albino mice at the doses of $200 \mathrm{and} 400 \mathrm{mg} / \mathrm{kg}$ body weight orally. Both extracts at both doses were administered for 13 consecutive days. After $24 \mathrm{~h}$ of the last dose and then eighteen hours of fasting, the mice were sacrificed and antitumor effect of ethanolic and aqueous extracts was assessed by evaluating tumor volume, viable and nonviable tumor cell count, tumor weight and hematological parameters of EAC bearing host. Ethanolic and aqueous extracts showed significant decrease in $(\mathrm{p}<0.0001)$ tumor volume, viable cell count, tumor weight and elevated the life span of EAC tumor bearing mice. Haematological profiles such as red blood cell (RBC), haemoglobin, and white blood cell (WBC) count reverted to normal level in treated mice. The results demonstrated that the extract has potent dose dependent anticancer activity comparable to that of cisplatin. Aqueous extract at both doses (200 and $400 \mathrm{mg} / \mathrm{kg}$ ) and ethanolic extract at $400 \mathrm{mg} / \mathrm{kg}$ dose showed potent anticancer activity.
\end{abstract}

Keywords: Dendrophthoe falcata, EAC cell line, anticancer activity, cisplatin.

\section{INTRODUCTION}

Cancer is one of the most dreaded diseases of the $20^{\text {th }}$ century and spreading further continuously with increasing incidence in 21 st century. Cancer is a group of more than 100 different diseases, characterized by uncontrolled cellular growth, local tissue invasion, and distant metastases [1]. Multidisciplinary scientific investigations are making best efforts to combat this disease, but the sure-shot, perfect cure is yet to be brought into world medicine. Cancer is caused by internal factors (tobacco, chemicals, radiations and infectious organisms) and external factors (mutation, hormones, and immune conditions) [2,3] and can be treated with surgery, radiation, chemotherapy, hormone therapy, and biological therapy. Plants have a long history of use in the treatment of cancer. Over $60 \%$ of currently used anti-cancer agents are derived in one-way or another from natural sources, including plants, marine organisms and microorganisms [4]. It is estimated that more than $50 \%$ of all the patients diagnosed with cancer explore complementary and alternative medicine - especially herbal medicine [5].

Dendrophthoe falcata (L.f.) Ettingsh. (known as mistletoe) is a perennial, climbing woody parasitic plant of the family Loranthaceae. It is indigenous to tropical regions especially in India, Srilanka, Thailand, China, Australia, Bangladesh, Malaysia, and Myanmar. In India, it is widely distributed and is commonly known as 'bandaa' and 'bandhulu'. The

*Address correspondence to this author at the Department of Pharmacognosy, Manipal College of Pharmaceutical Sciences, Manipal University, Manipal-576 104, Karnataka, India; Tel: 0820-2522482; Fax: 0820-2571998; E-mail: avemaria_lobo@yahoo.com medicinal properties of $D$. falcata are greatly influenced by the host plant. For example, when grown on Calotropis gigantea (L.) W.T. Alton (Asclepiadaceae), the parasitic plant is considered useful for improving cognitive function [6] However, when it is grown on Tamarindus indicus L. (Fabaceae), it is used to treat impotence and on Shorea robusta Gaertn. f. (Dipterocarpaceae), it is used to treat paralysis by the tribes of the Bihar state of India [6]. In addition to its medicinal values, the fruits taste sweet and are consumed as a food [6]. The entire plant is used extensively in traditional medicine as an aphrodisiac, astringent, narcotic, diuretic, and for the treatment of pulmonary tuberculosis, asthma, menstrual disorders, swellings, wounds, ulcers, strangury, renal and vesical calculi [7]. The various uses of this plant were studied in different ethnic groups of Nepal. The leaf paste is reported to be used for skin diseases and is taken in abortion while its paste along with Urtica doica L. (Urticaceae) is used to treat bone fractures [8]. Bark juice/decoction is used in menstrual troubles and asthma while its paste is applied on boils, setting dislocated bones and extracting pus. The fruit is taken as flavour, astringent, narcotic and for curing wounds while its paste is applied on fractures for setting bones. The decoction of the whole plant is used by the Kokru tribe in Maharashtra to treat joint pain [9], and the Valaiyan community in Tamil Nadu uses leaf juice for relief from chest pain [10]. Nair and Krishnakumary (1989) isolated and reported different flavonoids, viz. quercetin, kaemferol, rutin, quercetrin etc., from $D$. falcata growing on six different host plants [11]. Three new triterpenes, $3 \beta$-acetoxy-1 $\beta$-(2-hydroxy-2propoxy)-11 $\alpha$-hydroxyolean-12-ene, $3 \beta$-acetoxy-11 $\alpha$ ethoxy-1 $\beta$-hydroxy-olean-12-ene and $3 \beta$-acetoxy-1 $\beta$ hydroxy-11 $\alpha$-methoxyolean-12-ene were isolated along with nine known compounds, $3 \beta$-acetoxy-1 $\beta, 11 \alpha$-dihydroxy- 
olean-12-ene, $3 \beta$-acetoxy-1 $\beta, 11 \alpha$-dihydroxy-urs-12-ene, 3 $\beta$-acetoxy-urs-12-ene-11-one, $3 \beta$-acetoxy-lup-20(29)-ene, 30 -nor-lup-3 $\beta$-acetoxy-20-one, (20S)-3 $\beta$-acetoxy-lupan-29oic acid, kaempferol-3-O- $\alpha$-L-rhamnopyranoside, quercetin-3-O- $\alpha$-L-rhamnopyranoside, and gallic acid from the methanolic extract of the fruits of $D$. falcata growing on Shorea robusta [12].

Pattanayak and Priyashree (2008) evaluated the hepatoprotective effect of ethanol and aqueous extracts of leaves of D. falcata using carbon tetrachloride induced liver damage in wistar albino rats and suggested the potential hepatoprotective activity of this plant [13]. Gupta and Kachhawa (2007) reported the potential contraceptive efficacy of methanolic extract of $D$. falcata stem in male albino rats [14]. Aleykutty et al. (1993) reported that the aqueous and alcoholic extract of $D$. falcata significantly increased the volume of urine and excretion of sodium, potassium and chloride ions and also caused a significant reduction in the weight of magnesium ammonium phosphate stones, thus indicating diuretic and antilithiatic activity [15]. The aqueous extract of leaves of $D$. falcata growing on Shorea robusta for the antitumor activity on 7, 12-Dimethylbenz[a]anthracene (DMBA) induced rat mammary tumor model and revealed $24.934 \%$ reduction in the tumor size at the dose level of 400 $\mathrm{mg} / \mathrm{kg}$, which was less than that of standard drug tamoxifen which exhibited reduction of $62.865 \%$ thus suggesting $D$. falcata as a source for anticancer drugs [16]. In the present study we evaluated antitumor activity of $D$. falcata against Ehrlich Ascites Carcinoma (EAC) in mice.

\section{MATERIALS AND METHODS}

\section{Plant Collection and Extraction}

Dendrophthoe falcata was collected from in and around Manipal, Karnataka, India, from mango (Mangifera indica L., Anacardiaceae) and jackfruit (Artocarpus heterophyllus Lam., Moraceae) as host plant in August 2009 and identified by Dr. Gopalakrishna Bhat, Taxonomist, Poorna Prajna College, Udupi, Karnataka. A voucher specimen (PP 564) has been deposited in the Department of Pharmacognosy, Manipal College of Pharmaceutical Sciences, Manipal University (Manipal, India). The-shade dried, stems (500 g) of the plant were coarsely powdered, and then extracted by ethanol using soxhlet extraction apparatus for ethanolic extract and by a mixture of chloroform and water (1:99) using maceration method for aqueous extract. The extracts were concentrated to remove the solvent completely under reduced pressure and stored in vacuo till use. The percentage yield of ethanolic and aqueous extracts were calculated and found to be $9.93 \%$ $\mathrm{w} / \mathrm{w}$ and $12.8 \% \mathrm{w} / \mathrm{w}$, respectively.

\section{Chemicals}

Sodium chloride, propylene glycol, tryphan blue, methyl violet, sodium sulphate, methylene blue (Merck Limited, Mumbai, India), cisplatin (Sigma Aldrich, USA). All other chemicals and reagents used were of pure analytical grade.

\section{Animals}

Male Swiss albino mice weighing 22-28 g were used in the experiment. They were obtained from Manipal Central animal house and were acclimatized to the experimental room having temperature $23 \pm 2{ }^{\circ} \mathrm{C}$, controlled humidity conditions, and 12-h light - dark cycle. Animals were caged in poly acrylic cages $(38 \times 23 \times 10 \mathrm{~cm})$ with maximum of four animals per cage. The mice were fed with standard food pellets and water ad libitum. Before commencement of the experiment the mice were acclimatized to laboratory conditions for 7 days. All procedures described were reviewed and approved by the University Animal Ethical Committee and study was conducted after obtaining ethical committee clearance from the Institutional Animal Ethics Committee of KMC, Manipal (IAEC/KMC/75/2009-2010).

\section{High-Performance Thin-Layer Chromatography (HPTLC)}

Qualitative densitometric high-performance thin-layer chromatography (HPTLC) analysis was performed to develop the characteristic fingerprint profile for the methanolic extract of stem of $D$. falcata.

\section{Preparation of Quercetin Standard Solution:}

A stock solution of standard quercetin $(1 \mathrm{mg} / \mathrm{mL})$ was prepared by transferring $5 \mathrm{mg}$ of quercetin (accurately weighed) into a $5 \mathrm{~mL}$ volumetric flask, dissolving in $2 \mathrm{~mL}$ methanol. It was then sonicated for $10 \mathrm{~min}$ and the final volume of the solutions was made up to $5 \mathrm{~mL}$ with methanol to get stock solutions containing $1 \mathrm{mg} / \mathrm{mL}$.

\section{Preparation of Sample Solution:}

Accurately weighed $100 \mathrm{mg}$ of dried methanolic extract of D. falcata was transferred to a $10 \mathrm{~mL}$ volumetric flask dissolving in $5 \mathrm{~mL}$ of methanol. It was then sonicated for 10 min and the contents of the flask were filtered through Whatman No. 1 paper (Merck, Mumbai, India). The final volume of the solution was made up to $10 \mathrm{~mL}$ with methanol to get stock solution of $10 \mathrm{mg} / \mathrm{mL}$.

\section{Instrumentation and Chromatographic Conditions:}

HPTLC was performed on $20 \mathrm{~cm} \times 10 \mathrm{~cm}$ aluminum backed plates coated with silica gel $60 \mathrm{~F}_{254}$ (Merck, Mumbai, India). Standard solution of quercetin and sample solution were applied to the plates as bands on the same chromatographic plate by use of a Camag (Muttenz, Switzerland) Linomat V sample applicator equipped with a $100 \mu \mathrm{L}$ Hamilton (USA) syringe. Ascending development was performed at room temperature $\left(28 \pm 2^{\circ} \mathrm{C}\right)$, with Ethyl acetate: Formic acid: Glacial acetic acid: Water (100:11:11:26 v/v/v/v) as mobile phase, in a Camag glass twin-trough chamber previously saturated with mobile phase vapour for $20 \mathrm{~min}$. After development, the plates were dried and then scanned at 366 nm with a Camag TLC Scanner-3.

\section{Acute Toxicity Study}

Acute toxicity study was carried out for ethanolic and aqueous extracts of $D$. falcata according to the method described by Litchfield and Wilcoxon, 1949 using male Swiss albino mice orally [17]. The LD50 values were found to be 4 $\mathrm{g} / \mathrm{kg}$ body weight respectively.

\section{Transplantation of Tumor}

The EAC induced mice were originally obtained from the animal house in Manipal. The EAC cells propagated for 12- 
14 days were used in experiment. The ascitic fluid from mice was drawn using an 18 gauge needle into sterile syringe and was tested for microbial contamination. Tumor viability was determined by Tryphan blue exclusion test and cells were counted using Haemocytometer. The ascitic fluid was suitably diluted in normal saline to get a concentration of $10 \times$ $10^{6}$ cells $/ \mathrm{mL}$ of tumor cell suspension. From this stock suspension $0.25 \mathrm{~mL}\left(2.5 \times 10^{6}\right.$ cells/mice $)$ was injected intraperitonially (i.p.) to obtain ascitic tumor.

\section{Treatment Schedule}

140 Swiss albino mice were used in the experiment, which were divided into seven groups $(n=20)$, they were fed with food and water ad libitum. All the animals in each groups received EAC Cells $\left(2.5 \times 10^{6}\right.$ cells/mouse i.p. $)$ except Group-I. This was taken as day '0'. Group-I animals served as normal saline control ( $5 \mathrm{~mL} / \mathrm{kg}$ i.p.) and group-II animals served as EAC control without any drugs. $24 \mathrm{~h}$ after EAC transplantation, groups-III and IV animals received ethanolic extract of D. falcata at a dose of 200 and 400 $\mathrm{mg} / \mathrm{kg}$ orally, groups-V and VI animals received aqueous extract at a dose of 200 and $400 \mathrm{mg} / \mathrm{kg}$ orally for 13 alternative days, respectively. Group-VII animals received reference drug cisplatin $(3.5 \mathrm{mg} / \mathrm{kg}$ i.p) on the first day [18]. After $24 \mathrm{~h}$ of the last dose and then $18 \mathrm{~h}$ of fasting, ten animals of each group were sacrificed by cervical dislocation to measure tumor volume, tumor weight, cell viability and haematological parameters and the rest of the animals were kept with food and water ad libitum to check percentage increase in life span (\% ILS) of the tumor host.

\section{Evaluation of the Antitumor Activity}

The antitumor activity of the ethanolic and aqueous extracts of D. falcata was measured in EAC animals using the following parameters: (1) Tumor volume: The ascitic fluid was collected from the peritoneal cavity of Swiss albino mice and the volume was measured by using a graduated centrifuge tube. (2) Tumor weight: The tumor weight was measured by taking the weight of the mice before and after the collection of the ascitic fluid from peritoneal cavity. (3) Percentage increase in life span: The effect of ethanolic and aqueous extracts of $D$. falcata on percentage increases in life span (\% ILS) of the animals was calculated on the basis of mortality of the experimental mice [19]. \%ILS = Mean survival time (MST) of treated group- MST of control group / MST of control group $\times 100$, MST $=$ Mean survival time, Mean survival time $*=[$ First Death + Last Death $] / 2$, *Time denoted by days. (4) Tumor cell count: The ascitic fluid withdrawn from the peritoneal cavity of the mice was taken with a WBC pipette and diluted 100 times with normal saline. A drop of the diluted cell suspension was placed on the Neubauer's counting chamber and the numbers of cells in the 64 squares were counted. (5) Viable/ nonviable tumor cell count by tryphan blue assay: The viability and nonviability of the cells were checked by tryphan blue assay. The cells were stained with tryphan blue $(0.4 \%$ in normal saline) dye. Upon staining, the viable cells did not take the stain while the non viable cells were stained blue. Cell count $=$ Number of cells $\times$ dilution factor / Area $\times$ thickness of liquid film. (6) Blood parameters: At the end of the experimental period, the next day after an overnight fasting, blood was withdrawn from the retro-orbital plexus and used for the estimation of haemoglobin $(\mathrm{Hb})$ content, red blood cell (RBC) count and white blood cell (WBC) count by using an automatic analyzer (ERMA INC Tokyo, - PEC-21 OVET).

\section{Statistical Analysis}

Statistical significance $(p)$ was calculated by one-way ANOVA between the treated groups and the EAC control group followed by Dunnett's post hoc test of significance where, $\mathrm{p}<0.05, \mathrm{p}<0.01$ and $\mathrm{p}<0.0001$ considered being significant, very significant and highly significant, respectively. All datas are expessed as mean \pm S.E.M $(n=10$ mice per group).

\section{RESULTS}

The ethanolic and aqueous extracts of $D$. falcata at the doses of 200 and $400 \mathrm{mg} / \mathrm{kg}$ body weight, when administered orally, elevated the MST and life span of EAC tumor bearing mice (ILS) (Table 1 and 2). The haematological profile such as RBC count and haemoglobin content increased (Fig. 1A and 1C) but the WBC count was decreased as compared to that of EAC control (Fig. 1B). The extracts showed increased nonviable cell count (Fig. 2B) and decreased viable cell count (Fig. 2A), tumor volume (Fig. 3) and tumor weight (Table 3) when compared to that of EAC control mice.

Co-chromatography of $D$. falcata extract along with quercetin as a marker revealed the presence of quercetin in the extract, with an Rf value of 0.33 (Fig. 4, 5 and 6).

Table 1. Effect of Various Extracts on Mean Survival Time (MST) in EAC Inoculated Mice (Mean \pm S.E.M)

\begin{tabular}{|c|c|}
\hline Treatment & MST (Days) \\
\hline \hline Control & 16.16 \\
\hline Cisplatin $(3.5 \mathrm{mg} / \mathrm{kg})$ & 40.66 \\
\hline Ethanolic $(200 \mathrm{mg} / \mathrm{kg})$ & 21.83 \\
\hline Ethanolic $(400 \mathrm{mg} / \mathrm{kg})$ & 24.00 \\
\hline Aqueous $(200 \mathrm{mg} / \mathrm{kg})$ & 26.80 \\
\hline Aqueous $(400 \mathrm{mg} / \mathrm{kg})$ & 30.16 \\
\hline
\end{tabular}

Table 2. Effect of Various Extracts on Percent Increase in Life Span

\begin{tabular}{|c|c|}
\hline Treatment & \% ILS \\
\hline \hline Control & - \\
\hline Cisplatin $(3.5 \mathrm{mg} / \mathrm{kg})$ & 151.60 \\
\hline Ethanolic $(200 \mathrm{mg} / \mathrm{kg})$ & 35.08 \\
\hline Ethanolic $(400 \mathrm{mg} / \mathrm{kg})$ & 48.51 \\
\hline Aqueous $(200 \mathrm{mg} / \mathrm{kg})$ & 65.84 \\
\hline Aqueous $(400 \mathrm{mg} / \mathrm{kg})$ & 86.63 \\
\hline
\end{tabular}



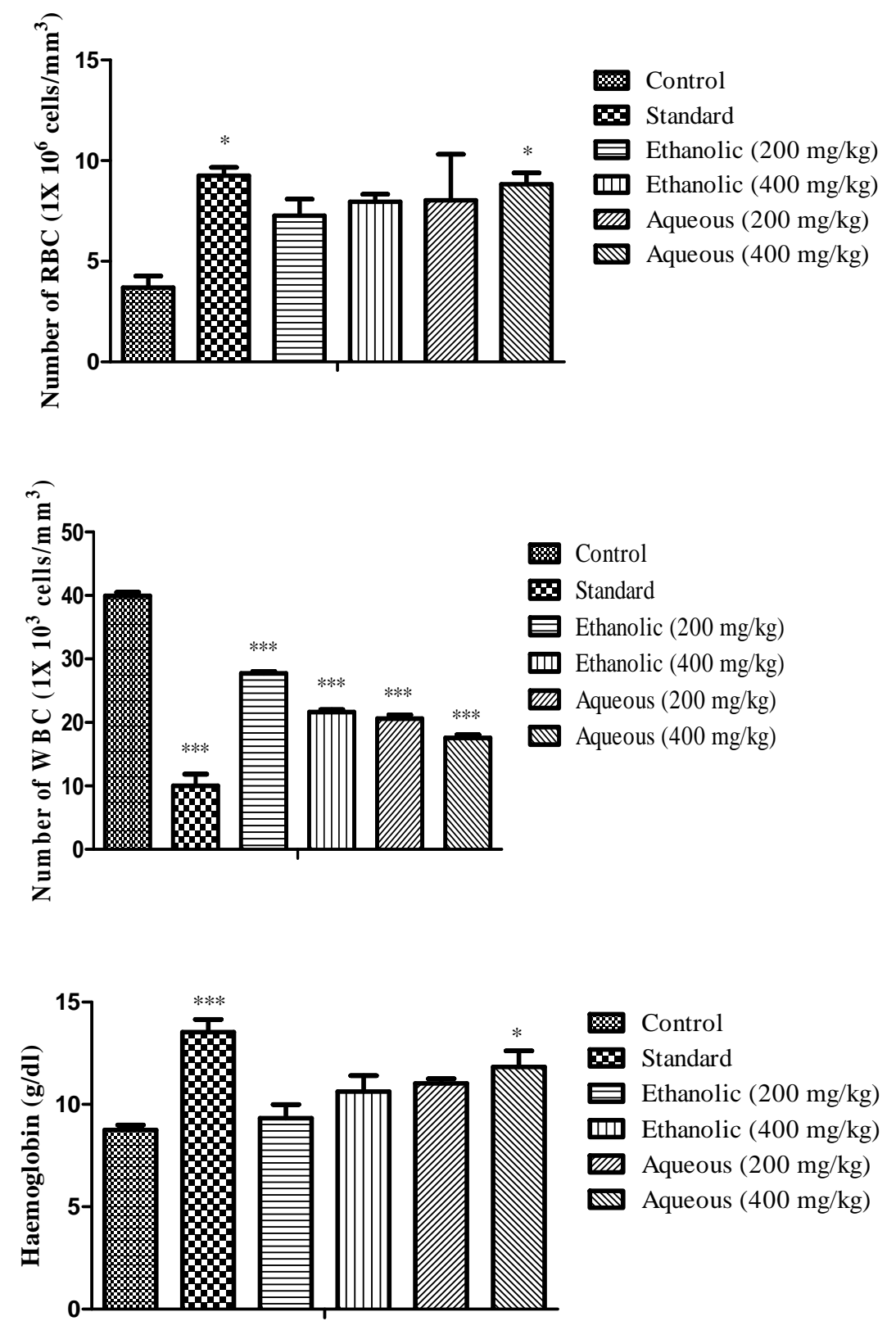

Fig. (1). Effects of various extracts on blood parameters. (A) RBC count; (B) WBC count; (C) Haemoglobin level. Each point represents the mean \pm S.E.M ( $n=10$ mice per groups). $* \mathrm{p}<0.05, * * \mathrm{p}<0.01$ and $* * * \mathrm{p}<0.0001$ when treated is compared with control.

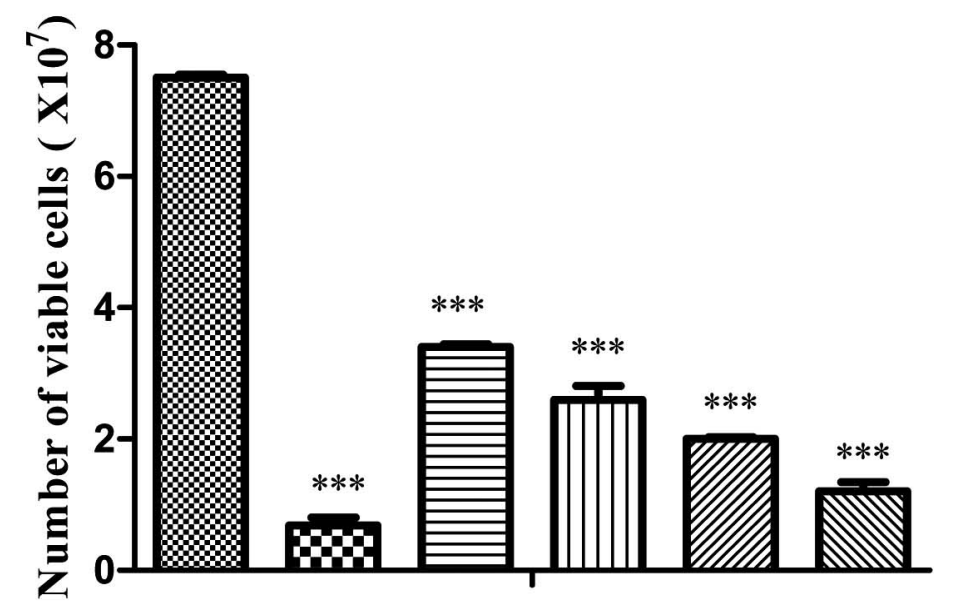

\& Control

Ex Standard

Ethanolic $(200 \mathrm{mg} / \mathrm{kg})$

Un Ethanolic $(400 \mathrm{mg} / \mathrm{kg})$

III Aqueous (200 mg/kg)

Aqueous $(400 \mathrm{mg} / \mathrm{kg}$ ) 
Fig. (2). Contd....

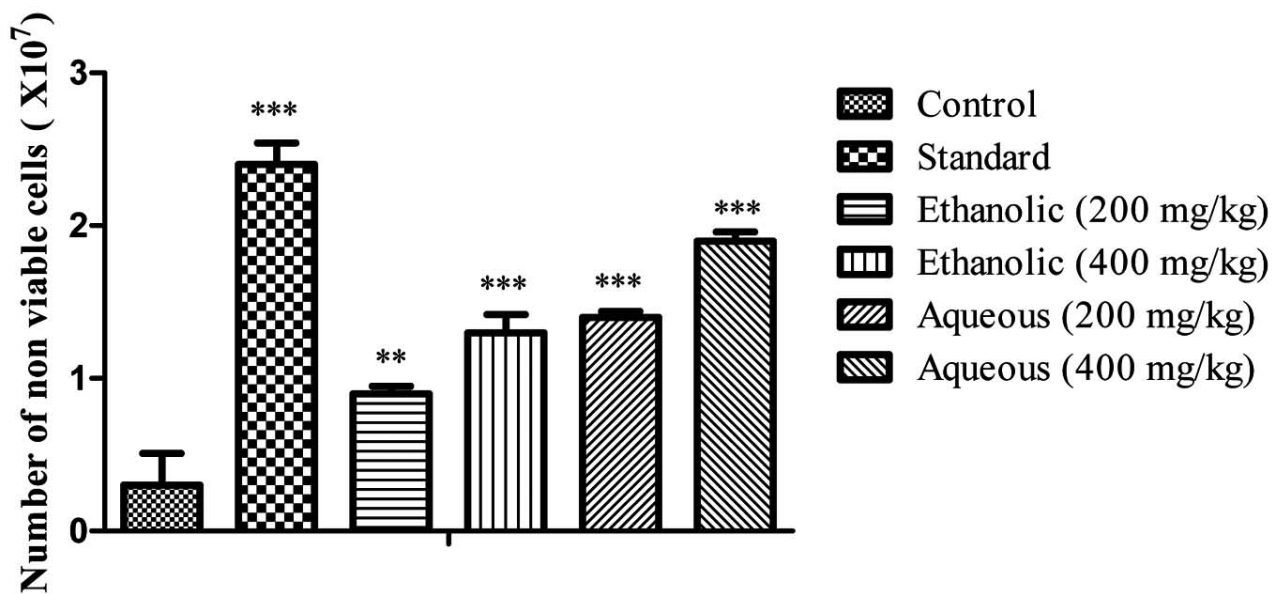

Fig. (2). Effects of various extracts on viability of cells. (A) Viable cells ; (B) Non-viable cells. Each point represents the mean \pm S.E.M ( $\mathrm{n}=10$ mice per groups). ${ }^{*} \mathrm{p}<0.05, * * \mathrm{p}<0.01$ and $* * * \mathrm{p}<0.0001$ when treated is compared with control.
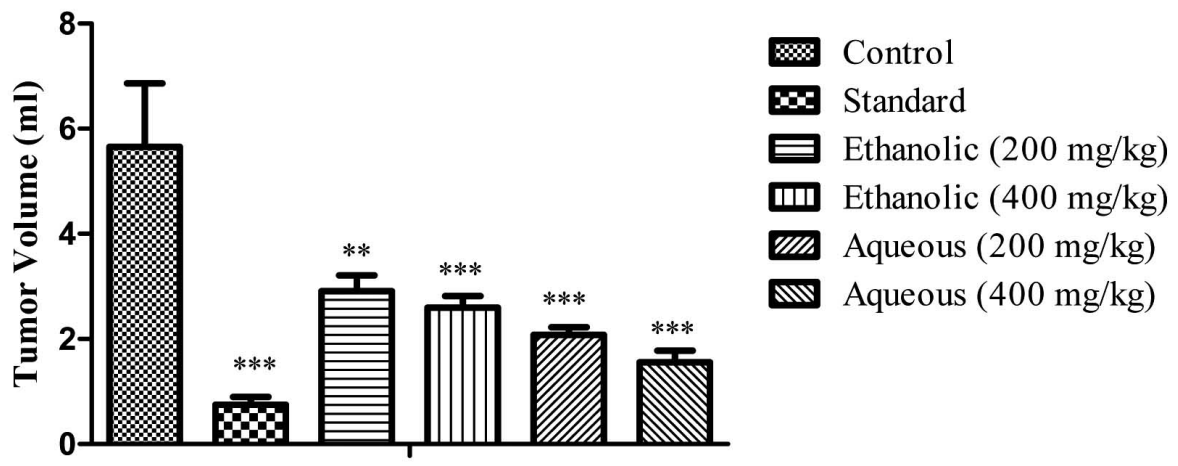

Fig. (3). Effects of various extracts on tumor volume.

Table 3. Effect of Various Extracts on Tumor Weight

\begin{tabular}{|c|c|}
\hline Treatment & Tumor Weight (g) \\
\hline \hline Control & $6.79 \pm 0.132$ \\
\hline Cisplatin $(3.5 \mathrm{mg} / \mathrm{kg})$ & $0.90 \pm 0.242^{* *}$ \\
\hline Ethanolic $(200 \mathrm{mg} / \mathrm{kg})$ & $3.49 \pm 1.385^{*}$ \\
\hline Ethanolic $(400 \mathrm{mg} / \mathrm{kg})$ & $2.72 \pm 0.740^{* *}$ \\
\hline Aqueous $(200 \mathrm{mg} / \mathrm{kg})$ & $2.19 \pm 0.194^{* *}$ \\
\hline Aqueous $(400 \mathrm{mg} / \mathrm{kg})$ & $1.96 \pm 0.920^{* * *}$ \\
\hline
\end{tabular}

Each point represents the mean \pm S.E.M ( $\mathrm{n}=10$ mice per groups). ${ }^{*} \mathrm{p}<0.05, * * \mathrm{p}<0.01$ and $* * * p<0.0001$ when treated is compared with control.

\section{DISCUSSION AND CONCLUSION}

The present study revealed that both ethanolic and aqueous extracts of D. falcata at the dose of 200 and $400 \mathrm{mg} / \mathrm{kg}$ significantly increased the life span of the mice when compared to the EAC control. The steadfast criteria for judging the potency of any anticancer drug are prolongation of life span and decrease in WBC [20]. The ethanolic and aqueous extracts delayed the cell division, thereby suggesting the reduction in EAC volume and increased survival time in mice.

Aqueous extract at both the doses (200 and $400 \mathrm{mg} / \mathrm{kg}$ ) and ethanolic extract $(400 \mathrm{mg} / \mathrm{kg})$ significantly improved the
MST in tumor bearing mice. No visible sign of toxicity and changes in vital functions were observed in any of treated animals. The prolongation of life span is a reliable criterion for judging efficacy of anticancer drugs [21] and the extracts of this plant were able to meet this criterion. Myelosuppression and anemia (reduced haemoglobin) have been frequently observed in ascites carcinoma [22, 23]. Anemia encountered in ascites carcinoma mainly due to iron deficiency, either by haemolytic or myelopathic conditions which finally lead to reduced RBC number [24]. In this study, elevated WBC count, reduced haemoglobin and RBC count were observed in EAC control mice, and the oral administration of D. falcata restored haemoglobin content and maintained normal values of RBC and WBC, thus supporting its haematopoietic protecting activity without inducing myelotoxicity, the most common side effects of cancer chemotherapy.

Preliminary phytochemical study indicated the presence of flavonoid, phytosterols and tannins in ethanolic extract and phytosterols, tannins and carbohydrates in aqueous extract [25]. Flavonoids such as quercetin, kaemferol and their glycosides have been shown to possess antimutagenic and antimalignant effect. Furthermore, flavonoids have a chemopreventive role in cancer through their effect on signal transduction in cell proliferation and angiogenesis [26]. The cytotoxicity and anticancer activity of ethanolic extract is probably due to the presence of thease flavonoids. Aqueous extracts reported the presence of phytosterols. Phytosterols are able to be incorporated into the cell membrane, alter mem- 


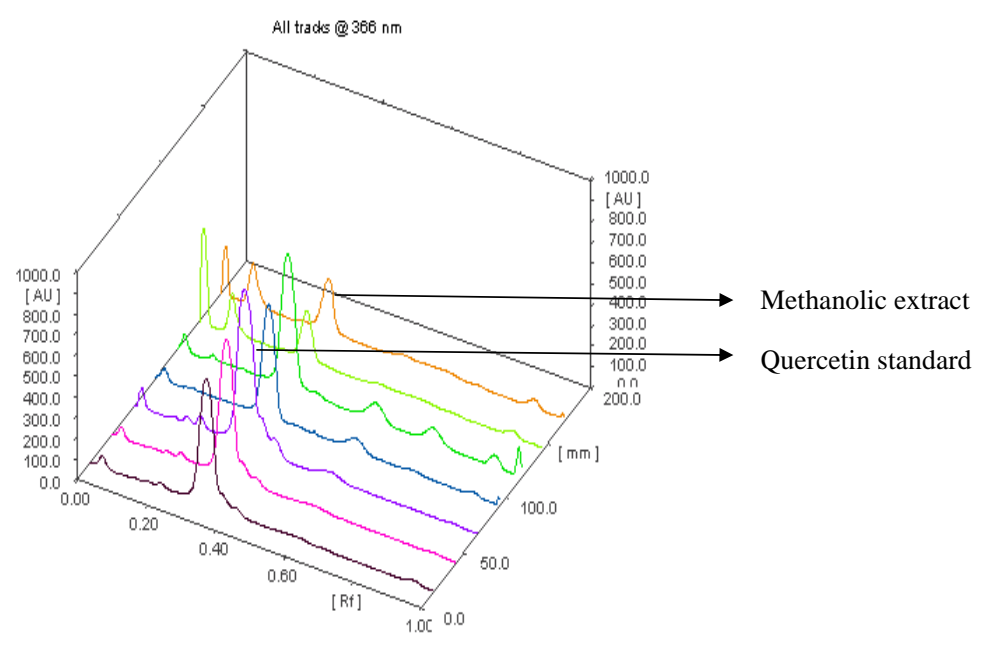

Fig. (4). 3-D chromatogram of Quercetin and Dendrophthoe falcata extract scanned at $366 \mathrm{~nm}$.

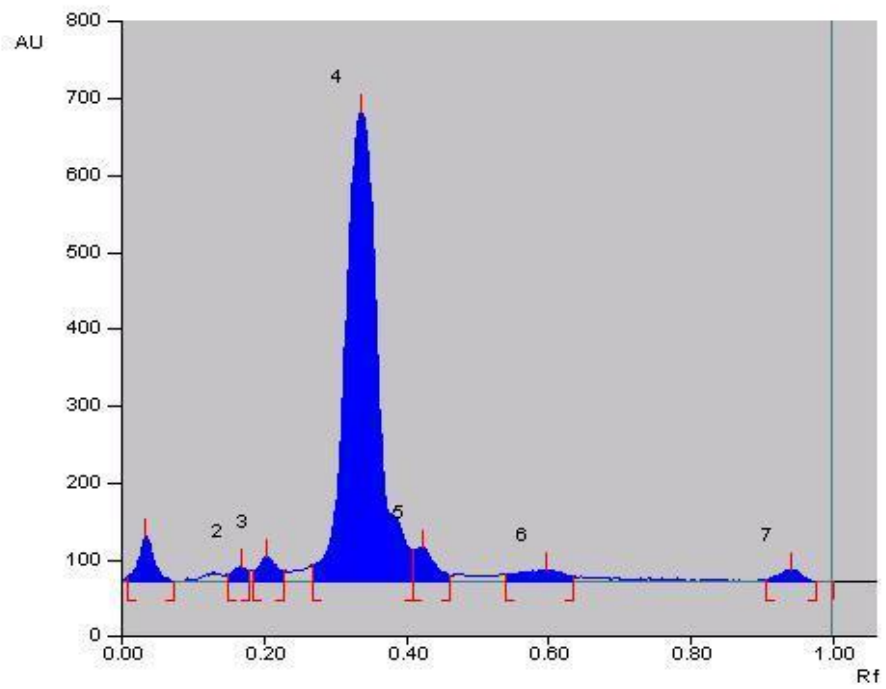

Fig. (5). HPTLC chromatogram of Quercetin.

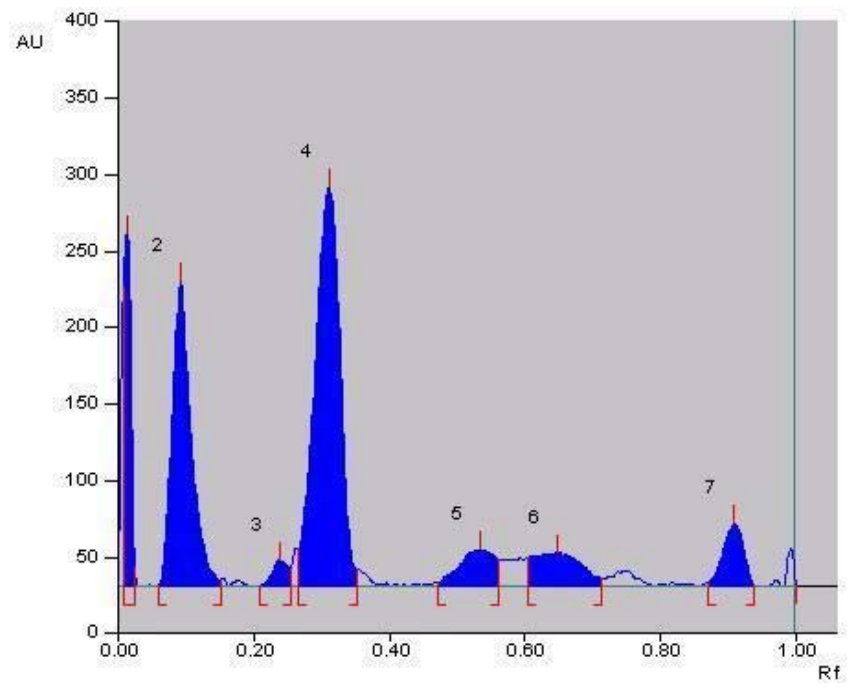

Fig. (6). HPTLC chromatogram of methanolic extract of Dendrophthoe falcata. 
brane fluidity and the activity of membrane-bound enzymes. They also alter signal transduction in pathways leading to tumor growth and stimulate apoptosis in tumor cell lines. They also have been shown to enhance in-vitro human peripheral blood lymphocyte and $\mathrm{T}$-cell proliferation in vitro, which suggests a possible stimulation of the immune system function [27]. Oleanolic acid, a triterpenoid is reported to be present in this plant extract [28] and known for its antitumor effect thus suggesting its possible role as antitumor agent. Therefore, further investigation in order to explore the potential of the aqueous extracts of $D$. falcata in tumor treatment may prove to be worthwhile.

\section{ACKNOWLEDGEMENT}

The authors sincerely thank Manipal University, Manipal College of Pharmaceutical Sciences Manipal, India for providing all facilities to carry out this study.

\section{ABBREVIATIONS}

$$
\begin{aligned}
& \text { DMBA }=7,12-\text { Dimethylbenz[a]anthracene } \\
& \text { EAC }=\text { Ehrlich Ascites Carcinoma } \\
& \text { HPTLC }=\text { High-performance thin-layer chromatography } \\
& \text { KMC }=\text { Kasturba Medical College } \\
& \text { LD50 }=\text { Lethal dose } \\
& \text { MST }=\text { Mean survival time } \\
& \text { RBC }=\text { Red blood cell } \\
& \text { WBC }=\text { White blood cell } \\
& \% \text { ILS }=\text { Percentage increases in life span }
\end{aligned}
$$

\section{REFERENCES}

[1] Kaufman, D.; Chabner, B.A.; Clinical strategies for cancer treatment: The role of drugs in Cancer Chemotherapy and Biotherapy: Principles and Practice; B.A Chabner, B.A.; Longo, D.L. Lippincott-Raven: Philadelphia, 1996; pp. 1-16.

[2] English, D.R.; Armstrong, B.K.; Kricker, A.; Fleming, C. Sunlight and cancer. Cancer Causes Control: CCC., 1997, 8(3), 271-83.

[3] Kuper, H.; Boffetta, P.; Adami, H.O. Tobacco use and cancer causation: association by tumour type. J. Intern. Med., 2002, 252(3), 206-24.

[4] Newman, D.J.; Cragg, G.M.; Snader, K.M. Natural products as sources of new drugs over the period 1981-2002. J. Nat. Prod., 2003, 66, 1022-37.

[5] Nelson, D.A.; Tan, T.T.; Rabson, A.B.; Anderson, D.; Degenhardt, $\mathrm{K}$.; White, E. Hypoxia and defective apoptosis drive genomic instability and tumorigenesis. Gene Dev., 2004, 18(17), 2095-107.

[6] Pattanayak, S.P.; Mazumder, P.M.; Sunita, P. Dendrophthoe falcata (L.f) Ettingsh: A consensus review. Pharmacog. Rev., 2008, 2, 359-68.

[7] Warrier, P.K.; Nambiar, V.P.K.; Ramankutty, C. Indian Medicinal Plants a Compendium of 500 Species, $2^{\text {nd }}$ ed.; Orient Longman: India, 1993.
[8] Kunwar, R.M.; Adhikari, N.; Devkota, M.P. Indigenous use of mistletoes in tropical and temperate region of Nepal. Banko Janakari., 2005, 15, 38-42.

[9] Jagtap, S.D.; Deokule, S.S.; Bhosle, S.V. Some unique ethnomedicinal uses of plants used by the Korku tribe of Amravati district of Maharashtra, India J. Ethnopharmacol., 2006, 107, 463-69.

[10] Sandhya, B.; Thomas, S.; Isabel, W.; Shenbagarathai, R. Ethnomedicinal plants used by the Valaiyan community of piranmalai hills (reserved forest), Tamil Nadu, India- A pilot study. Afr. $J$. Trad. CAM., 2006, 3, 101-14.

[11] Nair, A.G.R.; Krishnakumary, P. Flavonoids from Dendrophthoe falcata Ettingsh growing on different host plants. Indian J. Chem. 1989, 29B, 584-85.

[12] Mallavadhani, U.V.; Narasimhan, K.; Sudhakar, A.V.; Mahapatra, A.; Li, W.; Breemen, R.B.V. Three new pentacyclic triterpenes and some flavonoids from the fruits of an Indian Ayurvedic plant Dendrophthoe falcata and their estrogen receptor binding activity. Chem. Pharm. Bull., 2006, 54, 740-44.

[13] Pattanayak, S.P.; Priyashree, S. Hepatoprotective activity of the leaf extracts from Dendrophthoe falcata (L.f) Ettingsh against carbon tetrachloride- induced toxicity in wistar albino rats. Pharmacog. Mag., 2008, 4, 218-22.

[14] Gupta, R.S.; Kachhawa, J.B.; Sharma, A. Effect of methanolic extract of Dendrophthoe falcata stem on reproductive function of male albino rats. J. Herb. Pharmacother., 2007, 7, 1-13.

[15] Aleykutty, N.A.; Srinivasan, K.K.; Gundu, R.P.; Udupa, A.C.; Keshavamurthy. Diuretic and antilithiatic activity of Dendrophthoe falcate. Fitoterapia, 1993, 64, 325-31.

[16] Pattanayak, S.P.; Sunita, P.; Mazumdar, P.M.; Panda, P.K. Evaluation of the anti-tumor activity of the aqueous extract of Dendrophthoe falcata on 7,12-dimethyl benz[a] anthracene induced rat mammary tumor model. Int. J. pharmacol Biol Sci., 2008, 2, 75-80.

[17] Litchfield, J.R.; Wilcoxon, F. A simplified method of evaluating dose effect experiments. J. Pharmacol. Exp. Ther., 1949, 96, 99-113.

[18] Gopal, M.; Shenoy, S.; Doddamani, L.S. Antitumor activity of 4amino and 8 methyl-4-(3diethylamino propylamino) pyramided [4',5':4,5] thieno (2,3-b) quinolines. J. Photochem. Photobiol. B., 2003, 72, 69-78.

[19] Sur, P.; Ganguly, D.K. Tea plant roots extract (TRE) as an antineoplastic agent. Planta Med., 1994, 60, 106-9.

[20] Oberling, C.; Guerin, M. The role of viruses in the production of cancer. Adv. Cancer Res., 1954, 2, 353-423.

[21] Hogland, H.C. Haematological complications of cancer chemotherapy. Semin. Oncol., 1982, 9, 95-102.

[22] Price, V.E.; Greenfield, R.E. Anemia in cancer. In J. P. Greenstein, A. Haddow (Eds.), Advances in cancer research; Academic Press, New York, 1950; pp. 199-200.

[23] Maseki, M.; Nishiagaki, I.; Hagishara, M.; Tamoda, Y.; Yagi, K. Lipid peroxidation levels and lipid content of serum lipoprotein fractions of pragnent subjects with or without pre-eclampsia. Clin. Chim. Acta., 1981, 41, 424-26.

[24] Fenninger, L.D.; Mider, G.B. In J. P. Greenstein, A. Haddow (Eds). Advances in cancer research; Academic Press, New York, 1954; pp. 244.

[25] Dashora, N.; Agrawal, R.; Prabhu, K.; Sodde, V.; Lobo, R. Pharmacognostical Evaluation of Dendrophthoe falcate. J. Pharm. Res., 2010, 3(5), 971-74.

[26] Fotsis, T.; Pepper, M.S.; Aktas, E.; Breit, S.; Rasku, S.; Adlercreutz, H. Flavonoid, dietary-derived inhibitors of cell proliferation and in vitro angiogenesis. Cancer Res., 1997, 57, 2916-21.

[27] Jones, J.; Peter, H.; AbuMweis.; Suhad, S. Phytosterols as functional food ingredients: linkages to cardiovascular disease and cancer. Curr. Opin. Clin. Nutr. Metab. Care., 2009, 12(2), 147-51.

[28] The Ayurvedic Pharmacopoeia of India, Part- I, Volume - V, Government of India, Ministry of Health and Family Welfare, Department of Ayush. 